to joke a little about Oedipal suffering,

to destroy with brilliant irony the cretinism of all the maiden aunts

in the world:

the one who demanded that you learn to play the guitar,

the one who made you recite whenever she came to visit,

the one who recommended vitamins,

the one who gave you her home-made biscuits.

You ought to use a poem to say horrible things about your friends:

the one with a dried up soul,

the other who got fat and had two illegitimate children who'll someday

inherit his name,

the one who sleeps with the woman you want, or

the one who calls you up at midnight,

the other who has bad taste and is also a moralist.

You ought to make use of poetry. But no.

Translated by David W. Young

\title{
Imaginary Biography of Graham Greene
}

Failure is a kind of death:

today you know with certainty

of a child's horror when the hummingbirds

fly across his window to the garden

and he sees them, stunned:

it is daybreak.

Terror is a plague

and you never got rid

of that lump in your throat;

think back to the silence of clinics

when the world was the space

you could cover on your wheelchair.

Don't forget the day you found out

happiness is so fragile

it can be shattered by a word.

Bear in mind you had to choose

between lying and loathing,

that you were a deceitful ghost, 
bear in mind the errors

you committed on account of style:

the raw flesh of habit, the solitary vice of guilt, the anxiety so poorly worn.

It won't be enough:

your voice a cold footstep over the past, you vomiting the worm of faith.

Don't forget the bright morning sun trapped in the room, the cherry tree in the courtyard, the cistern among mulberries, the flashes of joy in the thick river of horror and remember that everything we could have been must already have been there for better or worse.

\section{Stories 2}

Esther tells your story:

(here we're talking about a thin air

that embroidered the house with a fragrance of timeless jasmine and a cold rage of outcast)

You fell in love.

You fell in love

and so far yours could be a shoddy love story:

your large lock of hair and the yellowish photo

that today looks remote and somnolent,

your faint nostalgia

of hallways where you swore love forever etcetera

and the clandestine notes that began

My love My sweet beloved

( sugar syrup-white lily-

butterfly-heart and soul).

It happens that to you everything became distance,

eternal silence in the books,

and sullen like an icon you frightened the children.

Ever since the No of your father

you refused to talk to anyone

and today I feel that thirty years is too long 